GRASAS Y ACEITES 66 (1)

January-March 2015, e056

ISSN-L: 0017-3495

doi: http://dx.doi.org/10.3989/gya.0691141

\title{
Mamey sapote seed oil (Pouteria sapota). Potential, composition, fractionation and thermal behavior
}

\author{
J.A. Solís-Fuentes ${ }^{1, \bowtie}$, R.C. Ayala-Tirado ${ }^{1}$, A.D. Fernández-Suárez ${ }^{1}$, and M.C. Durán-de-Bazúa, 2, \\ ${ }^{1}$ Instituto de Ciencias Básicas, Universidad Veracruzana. Av. Dos Vistas s/n carretera Xalapa-Las Trancas, 91000 Xalapa, Ver., México \\ ${ }^{2}$ Facultad de Química, UNAM. Conjunto "E”, Labs E301-E302-E303, Ciudad Universitaria, 04510 México, D.F. \\ ${ }^{\square}$ Corresponding authors: jsolis@uv.mx; mcduran@servidor.unam.mx
}

Submitted: 05 June 2014; Accepted: 10 September 2014

\begin{abstract}
SUMMARY: The chemical composition of the waste from mamey sapote (Pouteria sapota) and its oil extracted from the seed (MSSO) of ripe and unripe fruits, was studied. The MSSO from ripe fruits was dry-fractionated, and the thermal and phase behaviors of its fractions and their mixtures with other known natural fats were analyzed. The main components of the mamey peel and the seed were crude fiber $(81.32 \%)$ and fat $(44.41 \% \mathrm{db})$, respectively. The seed oil contained oleic, stearic, palmitic and linoleic as its main fatty acids. The MSSO showed a simple thermal behavior with a broad fusion range and four maximum temperature peaks. The solid fractions showed maximum melting peaks at higher temperatures than the residual liquid. The MSSO solid fractions showed a potential for use as constituents in mixtures with other natural fats, such as cocoa butter or mango seed fat.
\end{abstract}

\section{KEYWORDS: DSC; Mamey sapote; Oil fractionation; Pouteria sapota; Seed oil}

RESUMEN: Aceite de semilla de Zapote Mamey (Pouteria sapota). Potencialidad, composición, fraccionamiento y comportamiento térmico. Se estudió la composición de los residuos del zapote mamey (Pouteria sapota) y del aceite extraído de la semilla (ASZM) de frutos maduros e inmaduros. El ASZM de frutos maduros fue fraccionado en seco y se analizó la conducta térmica y de fase de las fracciones y mezclas de éstas con otras grasas naturales conocidas. Los principales componentes de la cáscara y de la semilla fueron fibra cruda $(81.32 \%$ bs $)$ y grasa $(44.41 \%$ bs), respectivamente. Los principales ácidos grasos del ASZM fueron: oleico, esteárico, palmítico y linoleico y mostró una conducta térmica simple con un intervalo de fusión amplio y cuatro máximos de temperatura. Las fracciones sólidas obtenidas presentaron máximos de fusión a temperaturas más altas que la fracción líquida residual. Las fracciones sólidas del ASZM mostraron potencialidad para usarse como constituyente en mezclas con la manteca de cacao y la grasa de la semilla de mango.

PALABRAS CLAVE: Aceite de semilla; DSC; Fraccionamiento de aceites; Pouteria sapota; Zapote mamey

Citation/Cómo citar este artículo: Solís-Fuentes JA, Ayala-Tirado RC, Fernández-Suárez AD, Durán-de-Bazúa, MC. 2015. Mamey sapote seed oil (Pouteria sapota). Potential, composition, fractionation and thermal behavior. Grasas Aceites 66 (1): e056. doi: http://dx.doi.org/10.3989/gya.0691141.

Copyright: (C) 2015 CSIC. This is an open-access article distributed under the terms of the Creative Commons Attribution-Non Commercial (by-nc) Spain 3.0 Licence.

\section{INTRODUCTION}

The effects of predominating exogenous cultural patterns promoted by the globalization of the world economy have often discouraged, in local contexts, the cultivation, use and consumption of indigenous plant species in detriment of the natural biodiversity. The case of $P$. sapota can exemplify the great potential of many various species from Mesoamerica to support its current and 
future populations (Solís-Fuentes and Durán-deBazúa, 2002).

The extensive family Sapotaceae is divided into five tribes with 53 genera and about 1250 species distributed worldwide, mainly in the tropical and subtropical regions of Asia and Mesoamerica. The Pouteria genus comprises 325 species (Triono et al., 2007). Many of them produce quality wood and edible fruits of high economic value; in addition, several of these species have been used in traditional medicine for various purposes (Silva et al., 2009).

Mamey sapote (tzapotl: fruit with bone and mama: hands, in Nahuatl language; Simeon, 2002; Nava-Cruz and Ricker, 2004) is, in Mexico and some parts of Central America, one of the vernacular names given to the fruit of P. sapota (Jacq.) H.E. Moore \& Stearn. It is an endemic plant growing in the warm climates of Mesoamerica, currently located, also, in some regions of North America, Asia and Africa.

The mamey sapote is a rounded, oval or elliptical fruit from 7.5 to $22.8 \mathrm{~cm}$ long and weighing between 0.227 and $2.3 \mathrm{~kg}$, with a rough and firm peel that resembles dark brown leather or bark. The fruit pulp has a sweet flavor like pumpkin and a color from salmon-pink to dark red. It has a long stone which is spindle-shaped, hard and bright brown. The kernel or seed is oily, bitter and with a characteristic odor like almonds (Morera, 1994). The edible part of mamey its pulp is mainly consumed fresh, but is also used for making jam, ice cream, sauces and other regional food products.

The mamey fruit is highly prized for its flavor and its acceptance is growing on the world market. However, there are few scientific reports on the chemical composition, physical properties and nutritional characteristics of its edible portion. There is limited knowledge too, of other parts of the fruit and the plant, despite its use and importance in some Mesoamerican indigenous cultures. It is known, for example, that in some towns, people still cook the seeds in water and then roast and mix them with cocoa for preparing chocolate. In Central America, the almonds are finely milled for making special confectionaries. The kernel or almond of this seed has served as a source of perfume essences. Traditional medicine recognizes that it has beneficial effects on coronary, rheumatic and kidney problems. The mamey seed oil has been used in the artisanal manufacturing of soap, ointments for the skin, hair conditioners and as sedative products for disorders of the eyes and ears (Morton, 1987; Morera, 1994).

In general, it is known that the seeds of the fruits, because of their biological functions, are rich in nutrients and are a source of vegetable fats, starches, proteins, and many compounds which are useful as raw or supplementary materials for elaborating other products in the food, pharmaceutical and cosmetics industries. The high oil content of the seed of the mamey sapote $(>40 \% \mathrm{db})$ has motivated some research designed to understand the oil extraction process, its chemical composition, physicochemical characteristics, and some other studies regarding its potential applications.

Oil extraction through the mechanical expression of the mamey seed was studied by Cravotto et al., (2011). They found that it is possible to obtain a high quality oil, free of contaminants and solvent residues, with a yield of up to $18 \%$ of the dry mass of the seed. Alvarez-Reyes et al., (2001) and Solis-Fuentes et al., (2001) studied the process of mass transfer during the extraction of seed oil with organic solvents and found that the process was affected by the particle size, the extraction time and the relationship of seed mass/solvent volume. Under certain conditions, it was possible to extract practically all of the oil contained in the sapote almonds. The apparent diffusivity coefficient of the oil from the unbroken seed cells was $6.9 \times 10^{-13}$ at $25^{\circ} \mathrm{C}$, a value whose magnitude is similar to that reported in the literature for other oilseeds, like peanuts and soybeans (Krasuk et al., 1967).

Laiz-Saldaña et al. (2009), showed the possibility of using mamey seed oil for biodiesel production, highlighting a favorable outlook from economic and technical points of view, since the mamey seed is still a residue. Nonetheless it has high oil content with a predominantly non-saturated fatty acids.

Today mamey oil is being reassessed beyond artisanal applications and has been analyzed in greater detail, for example, it is acquiring an interesting position as a source of triterpene alcohols, whose properties are interesting for applications in cosmetics (it is commonly considered to be effective in skin care and its healing, to improve tolerance to UV radiation, etc.) and pharmacology (anti-inflammatory capacities, erythema and sunburn treatments, etc.) (Parodi Nutra, 2013; De la Llata-Romero, 2013).

One aspect, sparsely addressed, is the potential use of this oil in the food sector where, because of its characteristics, it could be an interesting source of vegetable fats with specific phase properties, obtained by means of oil fractionation or oil mixing processes (Timms, 1985, 2005, 2006). This issue is important in the ongoing efforts to replace fats that currently are produced through industrial processing with the partial hydrogenation of oils; this results in fats with high contents of trans fatty acids, compounds with serious objections from nutritional and public health points of view (Precht and Molkentin, 1995; Khosla and Sundram, 1996; Tarrago-Trani et al., 2006).

The fractionation of vegetable oils is a process that, in recent decades, has been strongly revalued due to the fact that it can produce vegetable fats from oils without severe thermal treatments, thus achieving more natural and healthy products (Tarrago-Trani et al., 2006). The dry fractionation of vegetable oils has significant advantages from 
an economic and environmental protection perspective compared to the wet fractionation of oils with organic solvents (Timms, 2006).

This paper summarizes some results of an investigation concerning the fruit of mamey sapote, mainly of its traditionally non-food waste portions, in order to further their comprehensive utilization through greater knowledge of their characteristics and potentiality as a source of raw materials. The aim of this study was to estimate the possibility of obtaining oils from residues of mamey sapote in its mature and immature states, to study the composition of the oil extracted and purified from the seed and to carry out the dry fractionation of the oil in order to establish its thermal and phase behavior, of great importance for comprehending its potential uses.

\section{MATERIALS AND METHODS}

\subsection{Sampling and percentage estimate for each component of the fruit}

Immature and mature fruits of P. sapota were randomly collected from the producing region located in the municipality of Emiliano Zapata in the State of Veracruz, Mexico. Fruits from each batch were weighed and the anatomical parts of each of them, peel, pulp, stone, and seed, were removed in order to estimate the average percentage of each relative to the total mass of the fruit.

\subsection{Chemical and proximal analyses of the peel, pulp and seed of mamey sapote}

The peel, pulp and seed of the mamey were physically and chemically analyzed in terms of their contents in moisture, ash, crude fiber, proteins and fats by using the official analysis techniques (Horwitzs, 1995). Lots of pulp and seed were studied in the two stages of development considered and characterized further into other relevant components. For the pulp, the stage of its physiological development was characterized through titratable acidity (by neutralization with an alkaline solution), reducing sugars and total sugars (with the Lane and Enyon method), $\mathrm{pH}$ (potentiometric method) and tannins (with the method of Folhin-Denis). The seeds were further analyzed for their tannin and cyanide contents (with the Folhin-Denis method and alkali titration) according to official analysis techniques (Horwitzs, 1995).

\subsection{Extraction and purification of mamey sapote seed oil (MSSO)}

The oil was extracted in a Soxhlet apparatus using hexane. The extraction was performed during periods of 6 hours from dehydrated and milled seeds (with about 15\% humidity) until the samples were completely exhausted. The solvent was removed from the resulting micelle in a rotary laboratory (Büchi RE 111) at reduced pressure.

The lipid fraction was stored in a container protected from light under refrigerated conditions until processing and/or analysis.

The obtained oil was purified by an adaptation of the Wesson method (Mehlenbacher, 1970). In this procedure, the oil was dissolved in petroleum ether (1:5 mass/volume) and $1 \mathrm{~mL}$ of a $14 \%$ potassium hydroxide solution was added to each gram of oil, with vigorous agitation; subsequently, $50 \%$ ethyl alcohol was added at 1:2.5 (mass/volume) based on the mass of oil, with agitation and then resting, until separation of the phases. The ether layer containing the neutral oil was processed to recover the purified oil. It was then stored under refrigeration $\left(-5^{\circ} \mathrm{C}\right)$ and protected from light until processing and/or analysis.

\subsection{MSSO physicochemical properties}

The refractive index, saponification value and iodine value of $M S S O$ were measured using official analysis techniques (Horwitzs, 1995).

\subsection{Fatty acid pattern of MSSO}

The oil was converted into the methyl esters corresponding to its fatty acids; then they were separated and analyzed through gas chromatography and mass spectroscopy in accordance with the methodologies described by Horwitzs (1995); Bannon et al. (1982) and Hendrikse et al. (1994).

The boron trifluoride method (Horwitzs, 1995) was used for oil esterification.

The analysis of fatty acid methyl esters was carried out in a Hewlett Packard model 5890 series II gas chromatograph (Hewlett Packard Co., Palo Alto, CA, USA), coupled to a JEOL SX-102A mass spectrometer with an electron ionization detector. The system had an AT Silar capillary column (Alltech Associates, Inc., Deerfield, IL, USA) $30 \mathrm{~m}$ long and $0.32 \mathrm{~mm}$ internal diameter and $0.25 \mu \mathrm{m}$ film thickness. A database that contains about 75000 compounds supplemented with the internal standards of methyl ester fatty acids (Sigma) was used for the identification of compounds. Helium was used at a flow of $0.4 \mathrm{~mL} \cdot \mathrm{min}^{-1}$ and $38 \mathrm{kPa}$; the inlet temperature was $250^{\circ} \mathrm{C}$ and the initial temperature of the oven was $100^{\circ} \mathrm{C}$. The temperature program was: 2 min at $100{ }^{\circ} \mathrm{C}$ and increments of $4{ }^{\circ} \mathrm{C} \cdot \mathrm{min}^{-1}$ till $180^{\circ} \mathrm{C}$ was attained. The mass analyzer operated in a mass range of $10: 450 \mathrm{~m} / \mathrm{z}$.

\subsection{Dry fractionation of MSSO}

MSSO fractionation was performed through a homogeneous crystallization by applying slow cooling and spontaneous nucleation (O'Brien, 1998; Timms, 2005). The procedure included: a) MSSO heating 
to $90{ }^{\circ} \mathrm{C}$ for $10 \mathrm{~min}$; b) controlled cooling for crystal nuclei formation in a circulation and refrigeration bath (Polyscience Model 911), for which the temperature was gradually reduced from $30^{\circ} \mathrm{C}$ until the appearance of crystalline nuclei $\left(26.5\right.$ and $\left.23.8^{\circ} \mathrm{C}\right)$; c) crystalline aggregates were allowed to grow over a sufficient time period at each temperature for the MSSO to form a sufficient solid fraction; d) the separation of the solid and liquid phases at the established temperatures was done in a Hettich (Tuttlingen, Germany) refrigerated centrifuge, model Universal 32R. The recovered fractions were placed in amber bottles and stored under refrigeration $\left(-5^{\circ} \mathrm{C}\right)$.

\subsection{Thermal behavior of MSSO and its fractions}

\subsubsection{Melting and crystallization profiles}

The melting and crystallization profiles of MSSO and its fractions were analyzed with a TA Instruments 910 and 2910 Differential Scanning Calorimeter (New Castle, DE USA), equipped with a thermal analysis data station (Thermal Analysis 2100). The purge gas was nitrogen at $20 \mathrm{~mL} \cdot \mathrm{min}^{-1}$ and indium (melting point of $156.6{ }^{\circ} \mathrm{C}$ and $\Delta \mathrm{H}_{\mathrm{f}}$ of $28.45 \mathrm{~J} \cdot \mathrm{g}^{-1}$ ) was used for calibration. Samples of 5 to $15 \mathrm{mg}$ were weighed in aluminum capsules with a TA Instruments Thermobalance (model 2950) and hermetically sealed. An empty sealed capsule of the same type was used as reference.

The DSC temperature program was:

1) Cooling to $-60{ }^{\circ} \mathrm{C}$ and heating at $10^{\circ} \mathrm{C} \cdot \mathrm{min}^{-1}$ till $90{ }^{\circ} \mathrm{C}$, for registering the profile and the enthalpy of melting.

2) Heating to $90{ }^{\circ} \mathrm{C}$ for $10 \mathrm{~min}$ and cooling at $10^{\circ} \mathrm{C} \cdot \mathrm{min}^{-1}$ till $-60^{\circ} \mathrm{C}$, for registering the profile and the enthalpy of crystallization.

To demonstrate the effect of thermal history and polymorphic effects, some samples of the fractions obtained were tempered prior to the DSC analysis by heating at $90^{\circ} \mathrm{C}$ for $5 \mathrm{~min}$ and cooling to room temperature (between 22 and $24^{\circ} \mathrm{C}$ ); then they were held at that temperature for 24 hours and, finally stored for 15 days at $5{ }^{\circ} \mathrm{C}$.

\subsubsection{Fat solid-liquid relationships of MSSO and its fractions}

The amount of solids in the oil samples in relation to the temperature was estimated on the basis of the calorimetric results obtained according to the method reported by Lambelet and Raemy (1983) and Menard and Sichina (2000), for which equation (1) and the program Origin 8 (OriginLab, 2007) were used.
$\operatorname{SFI}(T)=\frac{\int_{T 0}^{T} H(T) d t}{\int_{T 0}^{T 1} H(T) d t}$

The partial areas of the thermograms were calculated and correlated with the percent of solids in the samples, considering that at $-60{ }^{\circ} \mathrm{C}$ the oil samples were $100 \%$ solid. Samples of cocoa butter (CB) and mango seed fat (MSF) and binary mixtures of MSSO fractions with these natural fats were prepared for the analysis of their thermal behavior and consistencies through the calculation of their solid-liquid relationships. In each one of the cases, binary mixtures were prepared with the solid fractions recovered from MSSO at 0.25, 0.50,75 and $100 \%$ of participation in the blends.

\section{RESULTS AND DISCUSSION}

\subsection{Morphology of the constituent parts of the immature and mature mamey fruits}

The tender (immature) and mature fruits showed qualitative differences under observation. The immature fruit, for example, presented a dark-brown, hard and gritty epicarp like that of the ripe fruit, but not fully differentiated from the pulp (mesocarp), which was light-brown and greenish in color, with a characteristic odor and an astringent taste. The stone was not well shaped and had a light brown color. The seed of the tender mamey showed relatively defined tissues and the presence of a weak seed coat (integument) with a higher moisture content than the mature one.

The ripe sapote fruit presented a distinct shell of mesocarp. The pulp was orange-red in color with a characteristic taste and odor. It had a well-defined stone, dark brown in color with a white ventral line, and a well-defined seed showing the presence of integument; seed tissues were firmer than the immature ones, and it had a lower water content than that of the immature fruit.

\subsection{Chemical composition of the mamey peel, pulp and seed}

Table 1 presents the percentage based on the mass of the main constituents of P. sapota fruit in its immature and mature states. The traditionally non-edible portions accounted for about $30 \%$ of the total mass of the fruit; the peel was between 16.21 and $14.54 \%$, the whole stone about $14 \%$, and the seed inside of the stone was 10.07 and $8.83 \%$ of the whole of the unripe and ripe fruits, respectively. The average mass of mature fruits was 
TABLE 1. Percentage of each constituent part of P. sapota fruit in its ripe and unripe state

\begin{tabular}{|c|c|c|c|c|}
\hline \multirow[b]{3}{*}{ Parts of the fruit } & \multicolumn{4}{|c|}{ Physiological state } \\
\hline & \multicolumn{2}{|c|}{ Unripe } & \multicolumn{2}{|c|}{ Ripe } \\
\hline & Mean \pm SD (g) & $\%$ & Mean \pm SD (g) & $\%$ \\
\hline Total mass of the fruit & $240.93 \pm 10.43$ & 100 & $529.98 \pm 81.53$ & 100 \\
\hline Pulp & $166.50 \pm 7.05$ & 69.10 & $376.04 \pm 70.16$ & 70.95 \\
\hline Peel & $39.06 \pm 3.62$ & 16.21 & $77.10 \pm 7.75$ & 14.54 \\
\hline Stone (whole) & $34.86 \pm 1.94$ & 14.46 & $75.86 \pm 10.06$ & 14.31 \\
\hline Integument & $0.0013 \pm 0.0005$ & 0.0005 & $0.0041 \pm 0.0007$ & 0.0007 \\
\hline Almond or kernel & $24.28 \pm 1.21$ & 10.07 & $46.80 \pm 9.89$ & 8.83 \\
\hline
\end{tabular}

slightly more than twice the weight of the immature sapotes.

The peel, morphologically well formed only in mature fruits, was composed mainly of crude fiber $(81.32 \% \mathrm{db})$ and had lower contents of protein $(6.48 \%)$, lipids $(6.3 \%)$ and ash $(3.89 \% \mathrm{db})$ (Table 2$)$.

The edible portion, the pulp, showed high moisture contents and carbohydrates, with simple sugars in ripe fruits and polysaccharides in immature ones.

The results in Table 2 for the pulp portion show the effects of the biological and structural changes due to maturation: an increase in $\mathrm{pH}$ and simple sugars at the expense of the starchy fraction; a lower content of moisture, organic acids and phenolic compounds (Table 2).

The almond-like portion or sapote seed was richer in lipids than the peel portion, with high values even in the earlier stage of physiological maturity $(28.31 \%)$. In mature fruits lipids represented an average of $44.41 \%(\mathrm{db})$, with pieces with close to $50 \%$ of oil having been found in the sapote seeds. This is remarkable if one takes into account that some important traditional sources of vegetable oils have similar or lower contents: $3.5-5 \%$ in corn, $18-20 \%$ in soybeans, $22-24 \%$ in cotton, and safflower and peanuts with $25-37 \%$ and $45-50 \%$ of oil, respectively. Other notable components in the seed were protein and crude fiber (Table 2).

\subsection{Physicochemical properties of MSSO}

The purified MSSO had a refractive index of 1.463 , a saponification value of $198 \mathrm{mg} \mathrm{KOH} / \mathrm{g}$ and an iodine value of $60 \mathrm{gI}_{2} \cdot 100 \mathrm{~g}^{-1}$ of oil.

\subsection{Fatty acid composition of MSSO}

The seed oil composition in immature and mature mamey is shown in Table 3. This composition is relatively simple, with the main fatty acids being palmitic, stearic, oleic and linoleic (10.7, 26.5, 53.5 and $5.6 \mathrm{~g}$ of FA. $100 \mathrm{~g}^{-1}$ of oil, respectively, for immature fruits and $10.5,28.6,48.6$, and $10.7 \mathrm{~g}$ of FA· $100 \mathrm{~g}^{-1}$ of oil,
TABLE 2. Chemical analysis of the main parts of the Mamey sapote (P. sapota) in immature and mature fruits

\begin{tabular}{|c|c|c|}
\hline \multirow[b]{3}{*}{ Part/Characteristic } & \multicolumn{2}{|c|}{ Stage of fruit development } \\
\hline & Immature & Mature \\
\hline & Mean \pm SD $^{a}$ & Mean \pm SD $^{a}$ \\
\hline \multicolumn{3}{|l|}{ Peel } \\
\hline Moisture & $\mathrm{NA}^{\mathrm{c}}$ & $44.25 \pm 0.06$ \\
\hline $\mathrm{Ash}^{\mathrm{b}}$ & NA & $3.89 \pm 0.07$ \\
\hline Oil & NA & $6.30 \pm 0.024$ \\
\hline Crude fiber & NA & $81.32 \pm 0.62$ \\
\hline Proteins & NA & $6.48 \pm 0.43$ \\
\hline $\mathrm{NFE}^{\mathrm{d}}$ & NA & $1.96 \pm 0.49$ \\
\hline \multicolumn{3}{|l|}{ Pulp } \\
\hline Moisture & $84.91 \pm 2.09$ & $61.53 \pm 0.42$ \\
\hline $\mathrm{pH}$ & $4.68 \pm 0.41$ & $5.29 \pm 0.07$ \\
\hline $\mathrm{Ash}^{\mathrm{b}}$ & $6.38 \pm 0.45$ & $3.57 \pm 0.13$ \\
\hline Total sugars & $13.87 \pm 0.54$ & $55.81 \pm 0.39$ \\
\hline Titratable acidity & $0.56 \pm 0.021$ & $0.383 \pm 0.001$ \\
\hline Tannins & $1.66 \pm 0.16$ & $0.037 \pm 0.002$ \\
\hline NFE & $77.51 \pm 0.58$ & $40.19 \pm 0.63$ \\
\hline \multicolumn{3}{|l|}{ Seed } \\
\hline Moisture & $83.84 \pm 3.23$ & $36.46 \pm 0.36$ \\
\hline $\mathrm{Ash}^{\mathrm{b}}$ & $3.19 \pm 0.70$ & $3.87 \pm 0.11$ \\
\hline Crude oil & $28.31 \pm 2.07$ & $44.41 \pm 1.66$ \\
\hline Crude fiber & $17.71 \pm 1.22$ & $25.69 \pm 0.53$ \\
\hline Proteins & $6.47 \pm 0.08$ & $11.34 \pm 0.05$ \\
\hline Tannins & $0.16 \pm 0.01$ & $0.177 \pm 0.006$ \\
\hline Cyanides & $0.28 \pm 0.12$ & $0.033 \pm 0.030$ \\
\hline NFE & $43.84 \pm 0.81$ & $14.45 \pm 2.11$ \\
\hline
\end{tabular}

${ }^{\mathrm{a}}$ Average and standard deviation of three determinations; ${ }^{\mathrm{b}}$ Percent values of dry matter; ${ }^{c}$ Not available; ${ }^{\mathrm{d}}$ Nitrogen free extract.

respectively, for mature ones). The ratio between saturated fatty acids (SFA) monounsaturated (MUFA) and polyunsaturated ones (PUFA) was 39.9, 48.6 and 10.7 , respectively, for $\mathrm{g} \cdot 100 \mathrm{~g}^{-1}$ studied in mature 
TABLE 3. Chemical composition of Mamey sapote seed oil (MSSO) extracted from immature and mature fruits

\begin{tabular}{lccc}
\hline & \multicolumn{2}{c}{ Stage of fruit development } \\
\cline { 2 - 3 } Fatty acid & Immature & Mature \\
\cline { 2 - 3 } Mean \pm SD $^{\mathbf{a}}$ & & Mean \pm SD $^{\mathbf{a}}$ \\
\hline Palmitic 16:0 & $10.79 \pm 0.035$ & $10.50 \pm 2.63$ \\
Stearic 18:0 & $26.57 \pm 3.96$ & $28.65 \pm 1.82$ \\
Oleic 18:1 & $53.59 \pm 1.87$ & $48.62 \pm 1.95$ \\
Linoleic 18:2 & $5.65 \pm 0.46$ & $10.77 \pm 0.01$ \\
Linolenic 18:3 & $0.27 \pm 0.01$ & $0.58 \pm 0.21$ \\
Arachidic 20:0 & $0.46 \pm 0.19$ & $0.36 \pm 0.19$ \\
Behenic 22:0 & $0.64 \pm 0.01$ & $0.40 \pm 04$ \\
N.I. & 2.03 & 0.3 \\
SFA $^{\mathrm{c}}$ & 38.46 & 39.91 \\
MUFA $^{\mathrm{d}}$ & 53.59 & 48.62 \\
PUFA $^{\mathrm{e}}$ & 5.92 & 11.35 \\
\hline
\end{tabular}

${ }^{\mathrm{a}}$ Mean and standard deviation of two determinations; ${ }^{\mathrm{b}} \mathrm{NI}$ : not identified; ${ }^{\mathrm{c}} \mathrm{SFA}$ : saturated fatty acids; ${ }^{\mathrm{d}}$ MUFA: monounsaturated fatty acids; ${ }^{\mathrm{e}}$ PUFA: polyunsaturated fatty acids.

fruits. These values are similar to those of some vegetable oils for industrial use such as palm oil, with the difference that, in the case of the mamey, stearic is its main saturated FA, similar to cocoa butter, one of the major industrial fats. However, in tropical zones at room temperature, sapote seed oil is a liquid and not a fat, due to the presence of high levels of oleic and linoleic acids in it.

\subsection{Thermal behavior for crystallization and melting of MSSO}

Figure 1 shows the crystallization and melting curves of MSSO. The thermal behavior in both phase changes is generally simple. The change from liquid to solid has a well-defined peak at $-2.3{ }^{\circ} \mathrm{C}$ and

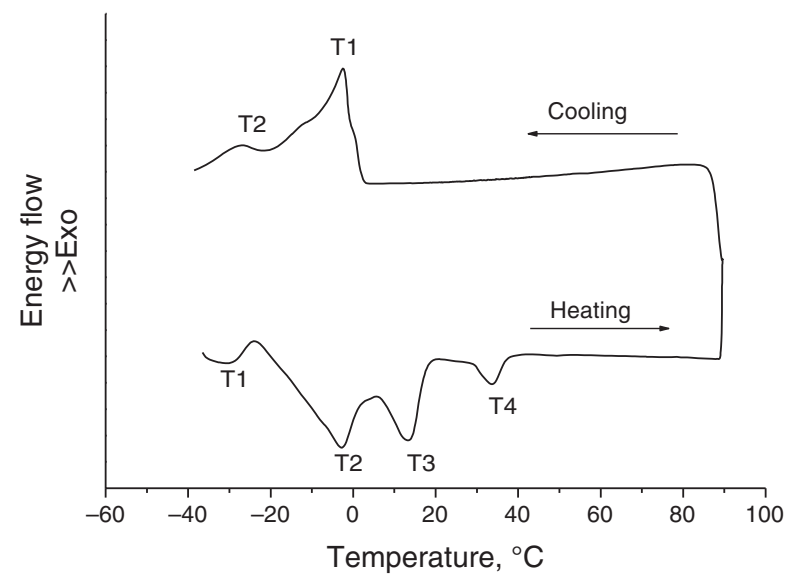

FIGURE 1. Melting and crystallization curves of MSSO. T1 to T4: Temperatures of phase transition. See Table 4. another in shoulder form at $-26.2{ }^{\circ} \mathrm{C}$. The crystallization onset temperature occurs at $4.5^{\circ} \mathrm{C}$ and this process extends over a range of $41.5^{\circ} \mathrm{C}$. The crystallization enthalpy was $32 \mathrm{~J} / \mathrm{g}$. The melting curve of the oil solidified by rapid cooling began at $-35.2{ }^{\circ} \mathrm{C}$ and it presented three well-defined maximum peaks $\left(-2.7,13.1\right.$ and $\left.34.4{ }^{\circ} \mathrm{C}\right)$ and a small shoulder $\left(-31.4^{\circ} \mathrm{C}\right)$; the process comprises a melting range of $73.2^{\circ} \mathrm{C}$ with a melting enthalpy of $28.6 \mathrm{~J} / \mathrm{g}$ (Table 4 ). Also, the thermal behavior of MSSO resembles that of palm oil (Tan and Che-Man, 2000); but the sapote oil has a broader melting range and that explains why this oil is liquid at ambient temperatures in tropical regions. The calorimetric analysis shows the existence of three groups of acylglyceride fractions with melting ranges at low, intermediate and high temperatures. This enables the attainment by fractionation of fats and oils with more specific thermal characteristics and phase behaviors, usable from the perspective of the extensive use of natural vegetable fats derived without the intervention of chemical processing and/or severe heating.

\subsection{MSSO dry fractionation and thermal behavior of its fractions}

The dry fractionation of MSSO oil yielded two solid fractions and a residual liquid fraction (RLF). The first two were obtained at 26.5 and $23.8^{\circ} \mathrm{C}$ (F1 and F2, respectively) and constituted 21.0 and $19.6 \%$, respectively, of the total oil subject to fractionation. The RLF remained liquid at temperatures of $23.8^{\circ} \mathrm{C}$, representing about $59 \%$ of the processed MSSO.

Figure 2 shows the melting curves of the fractions obtained by heating them $\left(10^{\circ} \mathrm{C} \cdot \mathrm{min}^{-1}\right)$ after their solidification by rapid cooling till $-60{ }^{\circ} \mathrm{C}$ (F1A, F2A and RLF), and the melting curves of the samples of these solid fractions after they were tempered (F1B and F2B). This last circumstance allowed for recording the effect of the polymorphism of the MSSO solid fractions.

The fractionation efficiency can be evaluated through the melting curves in terms of their different phase behavior, that is, between the RLF and the two solid fractions; however, it is possible to notice some similarities in the curves for the solid fractions. It is known that the process of dry fractionation requires the formation of large crystals to ensure efficient separation of the fractions. Said crystals however, forming larger clusters, trap some of the remaining liquid oil or olein, which, added to the conditions prevailing during the separations of the phases, may result in fractions of "light stearin" or low yields of the liquid fraction (O'Brien, 1998).

The melting curves in Figure 2 show that RLF culminates by melting at $21^{\circ} \mathrm{C}$; the other fractions end up melting at $34.9^{\circ} \mathrm{C}(\mathrm{F} 2 \mathrm{~A})$ and $39.5^{\circ} \mathrm{C}(\mathrm{F} 1 \mathrm{~A})$. Molecular rearrangements favored by slow cooling 
TABLE 4. Comparison of the transition temperatures during the crystallization and melting of mamey seed oil and its fractions

\begin{tabular}{lcrrrrrr}
\hline & & \multicolumn{7}{c}{ Transition temperatures $\left({ }^{\circ} \mathbf{C}\right)$} \\
\cline { 3 - 7 } Curve & $\mathbf{T}_{\mathbf{F}}-\mathbf{T}_{\mathbf{0}}\left({ }^{\circ} \mathbf{C}\right)^{\mathbf{c}}$ & \multicolumn{1}{c}{$\mathbf{T}_{\mathbf{0}}$} & \multicolumn{1}{c}{$\mathbf{T}_{\mathbf{1}}$} & $\mathbf{T}_{\mathbf{2}}$ & $\mathbf{T}_{\mathbf{3}}$ & $\mathbf{T}_{\mathbf{4}}$ & $\mathbf{T}_{\mathbf{F}}$ \\
\hline Crystallization & & & & & & & \\
MSSO $^{\mathrm{a}}$ & 41.5 & 4.5 & -1.8 & -27.4 & - & - & -37.0 \\
Melting & & & & & & & \\
MSSO & 73.2 & -35.2 & -31.4 & -2.7 & 14.1 & 34.0 & 38.0 \\
RLF (A) & 43.1 & -22.1 & 2.9 & 13.2 & - & - & 21.0 \\
F1(A) & 52.0 & -12.5 & -1.9 & 9.7 & 27.2 & - & 39.5 \\
F2(A) & 45.5 & -10.6 & 9.50 & 23.49 & - & - & 34.9 \\
F1(B) & 70.8 & -26.0 & 2.85 & 25.6 & 37.3 & - & 44.8 \\
F2(B) & 61.6 & -12.6 & -3.5 & 14.8 & 37.7 & - & 49.0 \\
\hline
\end{tabular}

${ }^{a}$ MSSO: Mamey sapote seed oil (whole); ${ }^{b} \mathrm{RLF}(\mathrm{A})$ : Residual liquid fraction crystallized by rapid cooling; F1(A): Fraction of minor melting point crystallized by rapid cooling; F2(A): Fraction of higher melting point crystallized by rapid cooling; F1(B): Fraction of minor melting point crystallized by slow cooling; F2(B): Fraction of higher melting point crystallized by slow cooling; ${ }^{c} \mathrm{~T}_{\mathrm{F}}-\mathrm{T}_{0}$ : Temperature range for the transition; $\mathrm{T}_{0}, \mathrm{~T}_{\mathrm{F}}$ : initial and final temperatures; $\mathrm{T}_{1,2,3}$ : Transition temperatures.

of the fractions resulted in changes to more stable crystalline forms or polymorphs $\left(\beta\right.$ and $\left.\beta^{\prime}\right)$ than $\alpha$. As it is known, lipids (fatty acids, acylglycerides, and fats and oils) are meta-stable and exhibit polymorphism during processing and storage. Generally and most commonly they solidify in three forms, the $\alpha$ form being the polymorph with the lowest melting point (it is obtained by rapid cooling from after melting). The $\beta^{\prime}$ polymorph, with a higher melting point than $\alpha$, is generated under certain conditions of temperature or by a spontaneous transition from the $\alpha$ form. The $\beta$ crystals are the most stable and

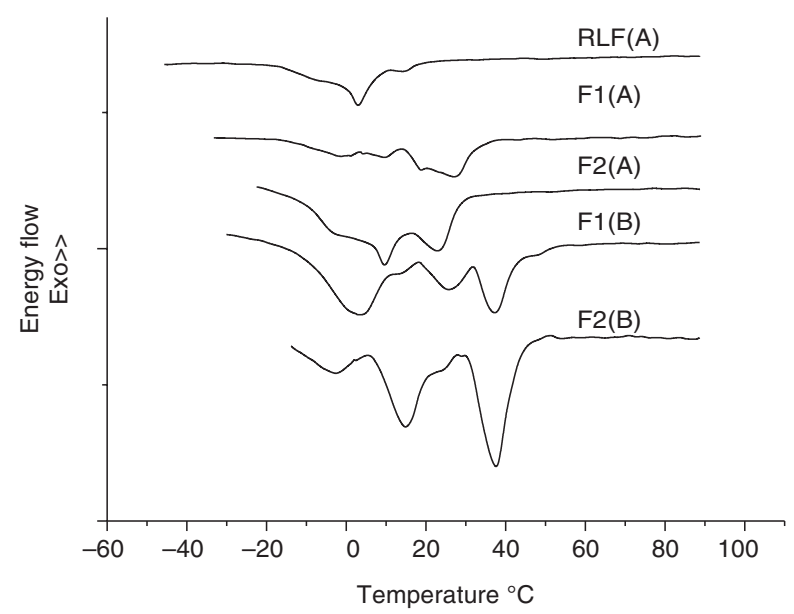

FIGURE 2. Melting curves residual liquid fraction and solid fractions obtained from MSSO with different thermal history. RLF(A): Residual liquid fraction crystallized by rapid cooling; F1(A): Fraction of minor melting point crystallized by rapid cooling; F2(A): Fractión of higher melting point crystallized by rapid cooling; F1(B): Fraction of minor melting point crystallized by slow cooling; F2(B): Fraction of higher melting point crystallized by slow cooling. are transitions of the above forms (Hagemann, 1988). In regard to such transitions, the molecular mobility, stability and their relationships are critical aspects for controlling the quality of the fatty products that are elaborated with these materials (Roos, 1995; Solís-Fuentes et al., 2005). The vast majority of phase transitions of lipids in foods, drugs and cosmetics associated with the behavior of processing, storage and use are established between the solid and liquid states and the different polymorphic forms of these materials (Roos, 1995; Sato, 1999).

Table 4 presents a comparison of the observable transition temperatures during the MSSO melting and its fractions. The stabilized fractions (F1B and F2B) exhibited higher end melting temperatures than their respective non-stabilized fractions (F1A and F2A), 44.8 and $49.0^{\circ} \mathrm{C}$, and 39.5 and $34.9^{\circ} \mathrm{C}$, respectively.

Figure 3 presents the solid-liquid relationship profiles of MSSO (measured as the percentage of solids) and its non-stabilized and stabilized fractions. As it is known, the ratio between the solid and liquid phases in the fat determines its consistency (i.e. hardness or firmness characteristics). These profiles include the four temperature zones in the fluency of triacylglycerols; this indirectly allows us to appreciate the lubrication properties and the primary structure of fats and oils in food products, that is, at refrigeration temperature $\left(10^{\circ} \mathrm{C}\right)$, environmental temperature $\left(21.1^{\circ} \mathrm{C}\right)$, body temperature $(36.3$ $37.8^{\circ} \mathrm{C}$ ) and of the preparation of fatty products $\left(40^{\circ} \mathrm{C}\right)\left(\mathrm{O}^{\prime}\right.$ Brien, 1998$)$.

According to its phase behavior, as shown in Fig. 3, the mamey seed contains an oil with the characteristics of a liquid fat because at $20{ }^{\circ} \mathrm{C}$ it has $6 \%$ solids; at $10{ }^{\circ} \mathrm{C} 25 \%$ and at $0{ }^{\circ} \mathrm{C}$ almost $50 \%$. 


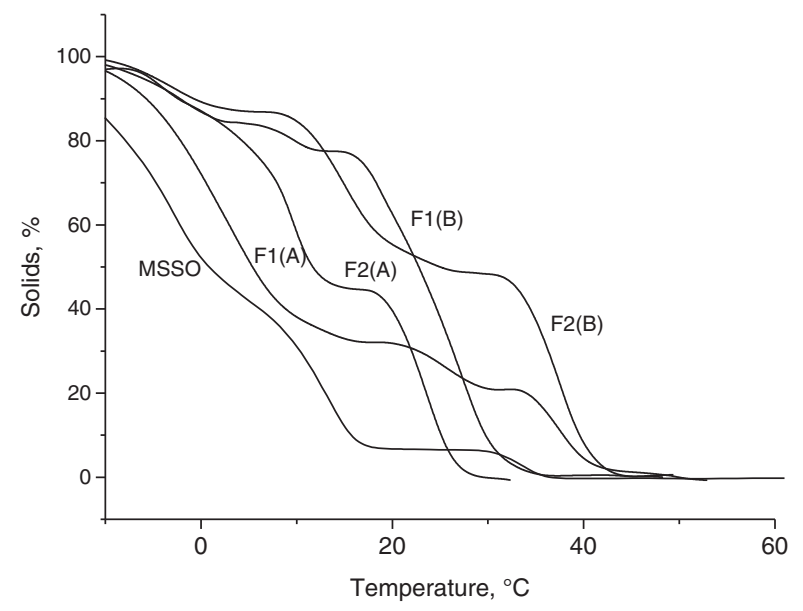

FIGURE 3. Profile of solid Fat of MSSO and solid fractions separated at 23.8 and $26.5^{\circ} \mathrm{C}$. MSSO: Mamey sapote seed oil; F1(A): Fraction of minor melting point crystallized by rapid cooling; F2(A): Fractión of higher melting point crystallized by rapid cooling; F1(B): Fraction of minor melting point crystallized by slow cooling; F2(B): Fraction of higher melting point crystallized by slow cooling.

Except for MSSO (and RLF, which is not presented in Fig. 3) which has a solid profile that gives the oil a liquid consistency at ambient temperatures in tropical regions $\left(20-22^{\circ} \mathrm{C}\right)$, all fractions showed solid consistency with a solid index $>35 \%$, which means that over a third of their acylglycerides in the solid-crystalline phase are suspended in less than two-thirds of liquid triglycerides at that temperature. This solid/liquid ratio decreases differently in these fats as the temperature rises and is minimized for all at around $40{ }^{\circ} \mathrm{C}$ (Fig. 3).

The stabilized samples, with polymorphic effects, showed important shifts in their solid profiles towards higher temperatures.

The solid fractions of MSSO showed different degrees of plasticity than those required for the manufacture of confectionery products, bakery shortenings and frying fats.

Figure 4 shows the solid profiles of blends of MSSO and its F2 solid fraction, with better known fats, such as cocoa butter (Theobroma cacao L., with a broad spectrum of industrial applications in the fields of food, pharmaceuticals and cosmetics), and mango seed fat (Mangifera indica, L., widely investigated in recent years; Solís-Fuentes and Durán Bazúa, 2004; Jahurul et al., 2014).

Curve B shows the solids profile of tempered cocoa butter $(\mathrm{CB})$ with its characteristic deep slope, a rapid decrease the percentage of solids at around human body temperature. This property is highly appreciated in the vast number of applications of this fat.

Curves C and D correspond to tempered mixtures whose weight contains $25 \%$ of the MSSO solid

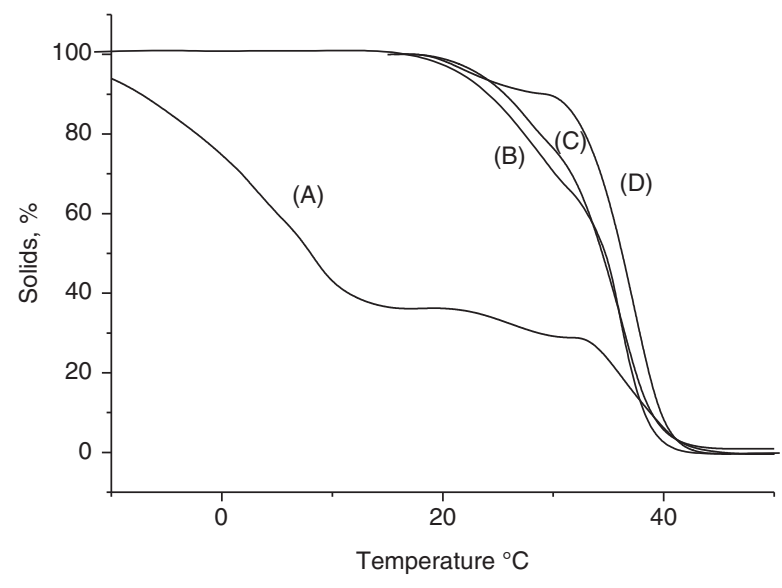

Figure 4. Profile of solid of mixtures of MSSO and its solid fraction (F2) with mango and cocoa fats. A) 75:25 MSSOMango seed fat; B) Cocoa butter; C) 25:75 MSSO(F2)-Cocoa butter; D) 25:75 MSSO(F2)-Mango seed fat.

fraction (F2A), with $75 \%$ of $\mathrm{CB}$ in one case and $75 \%$ of mango seed fat (MSF) in the other, respectively. In both cases, a great similarity in the solids profile to that of the fat model CB is evident. In the first case, the approximation to the CB curve is very close, and represents the possibility of partial substitution with this fraction of MSSO in products that use $\mathrm{CB}$ as the fat ingredient. In the second case (curve D), it is shown that the mixture of two nonconventional natural fats such as MSF and the solid fraction of MSSO have a phase behavior close to that of $\mathrm{CB}$.

\section{CONCLUSIONS}

P. sapota is a multi-purpose plant endemic to Mesoamerica and has been used since prehispanic times. Its fruit, prized for the characteristics of its flesh, has been used for domestic and artisanal purposes in the different cultures of America. Mamey sapote consumption generates waste of great potential as a source of raw materials for the production of different products that are currently being scientifically, technically and economically evaluated.

According to the results of this work, mameys contain about $30 \%$ of waste portions. In mature and immature fruit, the peel represents about $16 \%$ and the stone about $14 \%$ of the fruit. The kernel of the stone or seed is of great interest mainly for its lipid and protein composition. The seed has a high content of oil even in its earlier stages of physiological maturity. This oil has been appreciated and used in the producing regions in traditional medicine and cosmetic applications, but currently its commercial use is still incipient. In MSSO the oleic, stearic, palmitic and linoleic fatty acids are predominant, as occurs in many vegetable fats and oils from various 
origins, and, are widely used in the food industry. The thermal and phase behavior of this oil is relatively simple, with a broad melting range $\left(73{ }^{\circ} \mathrm{C}\right)$ and three maximum melting temperature peaks at $-2.7,13.1$ and $34.4{ }^{\circ} \mathrm{C}$.

The dry fractionation of MSSO allowed for its separation into three fractions, two solid and one liquid at room temperature (about $22^{\circ} \mathrm{C}$ ). The solid fractions, with different thermal and phase behavior and solid-liquid relationships, had the physical characteristic of natural vegetable fats.

Once stabilized, the obtained solid fractions showed significant shifts in their solid percentage toward higher melting temperatures as an effect of the polymorphic transitions.

Mixtures of the solid fractions of MSSO with other natural fats, such as CB and MSF, showed their potential as fatty constituent in the design of substitutes or equivalents for fats of industrial interest such as $\mathrm{CB}$.

\section{ACKNOWLEDGEMENTS}

The authors wish to thank the Institute of Materials Research of the UNAM for its support to the realization of the calorimetric analysis included in this work.

\section{REFERENCES}

Álvarez-Reyes AR, Solís-Fuentes JA, Durán-de-Bazúa MC. 2001. Coeficientes de difusividad aparente durante la extracción de aceite de almendras de zapote mamey (Pouteria sapota). Tecnol. Ciencia Ed. IMIQ. 16, 20-27.

Bannon CD, Craske JD, Hai NT, Harper NL, O'Rourke K. 1982. Analysis of fatty acid methyl esters with high accuracy and reliability II. Methylation of fats and oils with boron trifluoride-methanol. J. Chrom. A, 247, 63-69. http://dx.doi. org/10.1016/S0021-9673(00)84856-6.

Cravotto G, Binello A, Orio L. 2011. Green extraction techniques for high-quality natural products. Agro-Food Industry Hi-Tech 22, 57-59.

De la Llata-Romero L. 2013. Method of obtaining total fixed lipids from seeds of the sapotaceae family, for the preparation of cosmetics and dermatological pharmaceutical compositions. USA Patent 545900 B2

Hagemann JW. 1988. Thermal behavior and polymorphism of acylglycerides. En Garti, N, Sato K (Eds.) Cristallization and Polimorphism of Fats and Fatty Acids, vol. 31. Marcel Dekker. NY, USA.

Hendrikse PW, Harwood JL, Kates M. 1994. Analytical methods. En The Lipids Handbook, Gunstone FD, Hornwood JL (Eds.) Chapman and Hall Chemical Database. NY, USA.

Horwitzs W. 1995. Official Methods of Analysis of the Association of Official Analytical Chemist. AOAC Washington DC, USA

Jahurul MHA, Zaidul ISM, Norulaini NAN, Sahena F, Abedin MZ, Ghafoor K, Mohd Omar AK. 2014. Characterization of crystallization and melting profiles of blends of mango seed fat and palm oil mid-fraction as cocoa butter replacers using differential scanning calorimetry and pulse nuclear magnetic resonance. Food Research International. 55, 103 109. http://dx.doi.org/10.1016/j.foodres.2013.10.050

Khosla P, Sundram K. 1996. Effects of dietary fatty acid composition on plasma cholesterol. Prog Lipid Res. 35, 93-132. http://dx.doi.org/10.1016/0163-7827(95)00014-3.
Krasuk JH, Lombardi JL, Ostrovsky CD. 1967. Difusión extaction of oil containing materials. Proc. Des. Dev. 6, 187-195. http://dx.doi.org/10.1021/i260022a006.

Lambelet P, Raemy A. 1983. Isosolid diagrams of fat from thermal analysis data. J. Am Oil Chem. Soc. 60, 845-847. http://dx.doi.org/10.1007/BF02787442.

Laiz-Saldaña JC, Tovar-Miranda R, Durán-de-Bazúa MC, Solís-Fuentes JA. 2009. Aprovechamiento de residuos agroindustriales: Producción de biodiesel por tranesterificación alcalina de aceite crudo de almendras de zapote mamey (Pouteria sapota) Tecnol. Ciencia Ed. (IMIQ). 24, $48-56$.

Mehlenbacher VC. 1960. Análisis de Grasas y Aceites, Enciclopedia de la Química Industrial, Tomo 6, Ediciones Urmo. España. Pág. 330-344.

Menard KF, Sichina WJ. 2000. Prediction of solid fat index (SFI) values of food fats using DSC. Perkin Elmer Application Note, p. 1-3.

Morera JA. 1994. Sapote (Pouteria sapota). In Neglected Crops:1492 from a Different Perspective. JE HernándoBermejo and J León (Eds.) Plant Production and Protection Series 26. Rome, Italy. 103-109.

Morton J. 1987. Sapote. In Fruits of Warm Climates. JF Morton, Miami, FL. EEUU.

Nava-Cruz Y, Ricker M. 2004. El Zapote Mamey (Pouteria sapota (Jacq) H. Moore y Stearn), un fruto de la selva mexicana con alto valor comercial. En Productos Forestales, Medios de Subsistencia y Conservación, Vol. 3 América Latina. Alexiades MN, Shanley P (Ed.). CIFI. Bogor Barat, Indonesia.

O’Brien R. 1998. Fats and Oils. Technomic Pub. Co. Lancaster, Penn. EEUU

OriginLab. 2007. Origin Pro 8 SRO. OriginLab Corporation. Northampton, MA, USA.

Parodi Nutra. 2013. Dossier scientifique sur l'huile de sapote pour un usage en cosmetique. Rapport d'etude Parodi Nutra CPO 0606013.

Precht D, Molkentin J. 1995. Trans fatty acids: implications for health, anlytical methods, incidence in edible fats and intake. Food Nahrung 39, 343-374.

Roos YH. 1995. Phase Transitions in Foods. Academic Press. Londres, Inglaterra.

Sato K. 1999. Solidification and phase transformation behavior of food fats, a review. Lipid-Fett. 101,467-474. http://dx.doi. org/10.1002/(SICI)1521-4133(199912)101:12<467::AIDLIPI467>3.0.CO;2-D.

Simeón R. 2002. Diccionario de la Lengua Náhuatl o Mexicano. Siglo XXI. México, DF. México.

Silva CAM, Simeoni LA, Silveira D. 2009. Genus Pouteria: Chemistry and biological activity. Brazilian J. Pharmacognosy 19, 501-509.

Solís-Fuentes JA, Tapia-Santos M, Durán-de-Bazúa MC. 2001. Aceite de almendra de zapote mamey, un análisis de rendimientos y condiciones de extracción. Información Tecnológica. 12, 23-28.

Solís-Fuentes JA, Durán-de-Bazúa MC. 2002. Indigenous Species Appropriate Use, a Support Towards Sustainability: Zapote Mamey (Pouteria sapota) in Mesoamerica. En, Li Dajue (Ed.) Proceedings of Second International Conference on Sustainable Agriculture for Food, Energy and Industry. Chinese Academy of Science. Beijing, China.

Solís-Fuentes JA, Durán-de-Bazúa MC. 2004. Mango seed uses: Thermal behaviour of mango seed almond fat and its mixtures with cocoa butter. Bioresour. Technol. 92, 71-78. http://dx.doi.org/10.1016/j.biortech.2003.07.003.

Solís-Fuentes JA, Hernández-Medel MR, Durán-de-Bazúa MC. 2005. Determination of predominant polymorphic form of mango (Mangifera indica) almond fat by differential scanning calorimetry and X-ray diffraction. Eur. J. Lipid Sci. Technol. 107, 395-401. http://dx.doi.org/10.1002/ ejlt.200401072.

Tan CP, Che-Man YB. 2000. Differential scanning calorimetric analysis of edible oils: Comparison of thermal properties and chemical composition. J. Am. Oil Chem. Soc. 77, 143155. http://dx.doi.org/10.1007/s11746-000-0024-6 
10 • J.A. Solís-Fuentes, R.C. Ayala-Tirado, A.D. Fernández-Suárez and M.C. Durán-de-Bazúa

Tarrago-Trani MT, Phillips KM, Lemar LE, Holden JM. 2006. New and existing oils and fats used in products with reduced trans fatty acid content. J. Am. Dietetic Assoc. 106, 867-880. http://dx.doi.org/10.1016/j.jada.2006.03.010.

Timms RE. 1985. Physical properties of oils and mixtures of oils. J. Am. Oil Chem. Soc. 62, 241-249. http://dx.doi. org/10.1007/BF02541385.

Timms RE. 2005. Fractional crystallization-the fat modification process for the 21st century. Eur. J. Lipid Sci. Technol. 107, 48-57. http://dx.doi.org/10.1002/ejlt.200401075.
Timms RE. 2006. Fractionation of palm oil: Current status, future possibilities. En Timothy L. Mounts Award Address presented at the AOCS World Conference and Exhibition on Oilseed and Vegetable Oil Utilization.

Triono T, Brown AHD, West JG, Crisp MD. 2007. A phylogeny of Pouteria (Sapotaceae) from Malesia and Australasia. Aust. Syst. Bot. 20, 107-118. http://dx.doi.org/10.1071/ SB06011. 